\title{
"Estimating systematic risk for the best investment decisions on manufacturing company in Indonesia"
}

\begin{tabular}{|c|c|}
\hline AUTHORS & Zarah Puspitaningtyas id http://orcid.org/0000-0002-1616-4822 \\
\hline ARTICLE INFO & $\begin{array}{l}\text { Zarah Puspitaningtyas (2017). Estimating systematic risk for the best investment } \\
\text { decisions on manufacturing company in Indonesia. Investment Management and } \\
\text { Financial Innovations, 14(1), 46-54. doi:10.21511/imfi.14(1).2017.05 }\end{array}$ \\
\hline DOI & http://dx.doi.org/10.21511/imfi.14(1).2017.05 \\
\hline \multirow[t]{2}{*}{ RELEASED ON } & Friday, 31 March 2017 \\
\hline & $(\mathrm{cc})$ EY-NC \\
\hline LICENSE & $\begin{array}{l}\text { This work is licensed under a Creative Commons Attribution-NonCommercial } 4.0 \\
\text { International License }\end{array}$ \\
\hline JOURNAL & "Investment Management and Financial Innovations" \\
\hline ISSN PRINT & $1810-4967$ \\
\hline ISSN ONLINE & $1812-9358$ \\
\hline PUBLISHER & LLC “Consulting Publishing Company "Business Perspectives" \\
\hline FOUNDER & LLC "Consulting Publishing Company "Business Perspectives" \\
\hline
\end{tabular}

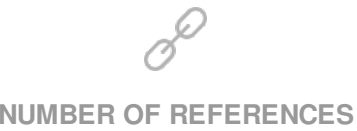

49

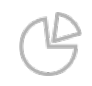

NUMBER OF FIGURES

0

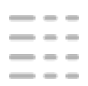

NUMBER OF TABLES

1

(C) The author(s) 2023. This publication is an open access article. 


\title{
Zarah Puspitaningtyas (Indonesia)
}

\section{Estimating systematic risk for the best investment decisions on manufacturing company in Indonesia}

\begin{abstract}
Estimation of systematic risk is one of the important aspects of the best investment decisions. Through systematic risk prediction will be known risks to be faced by investors, because systematic risk is a measure of investment risk. In addition to returns, investors always consider the risk of investment, because investors are rational individuals, ie individuals who always consider the trade-off between return and risk. At a certain level of return, investors will tend to choose investments with the lowest risk level. Conversely, at a certain level of risk, investors tend to choose investments with the highest return rate. The purpose of this paper is to analyze the influence of the financial information on the systematic risk of stock manufacturing companies listed on the Indonesia Stock Exchange over a period of five years from January 2011 to December 2015. The financial information is measured in four accounting variables, i.e. financial leverage, liquidity, profitability, and firm size. The results of data analysis using multiple linear regression method to prove that at the 0.05 level only variable sized companies that significantly influence systematic risk. Meanwhile, the variable financial leverage, liquidity, and profitability does not affect the systematic risk. The results showed inconsistencies with the results of several previous studies. This inconsistency may be due to measurement problems variable accounting, the implementation period of the study, and the use of different research samples.
\end{abstract}

Keywords: systematic risk, investment decision, financial information.

JEL Classification: G11, G17, N25.

\section{Introduction}

Estimation of risk is important to achieve the best investment decisions. One of them, conducted by predicting systematic risk by using financial information presented in the financial statements. Investor as one of the investment decision maker is always assumed to be a rational individual, that individual is risk averse or risk neutral. That is, individuals consider the trade-off between expected return and risk in investment decisions (Bera and Kannan, 1986; Scott, 2009; Puspitaningtyas, 2012).

Risk and return relations are positive and linear. The higher the risk, the higher the expected return, and vice versa. Thus, investor expectations for investment decisions are to obtain the maximum return with a certain level of risk (Sudarsono, Husnan, Tandelililn and Ekawati, 2012; Puspitaningtyas, 2012). Theory of investment in the concept of Capital Asset Pricing Model (CAPM) defines risk as beta $(\beta)$. Investment theory also states that an investor would consider only for the level of risk that can not be eliminated through diversification, so that the size of the risk is still relevant is the systematic risk (Fama and French, 2004; Homan, 2006; Anjum, 2014). Thus, systematic risk is a measure of investment risk and are defined as beta $(\beta)$. Although, Lai and Stohs (2015) have proved that CAPM has died.

\footnotetext{
(c) Zarah Puspitaningtyas, 2017

Zarah Puspitaningtyas, Department of Business Administration, University of Jember, Indonesia.

This is an Open Access article, distributed under the terms of the Creative Commons Attribution-NonCommercial 4.0 International license, which permits re-use, distribution, and reproduction, provided the materials aren't used for commercial purposes and the original work is properly cited.
}

The purpose of this paper is to analyze the influence of the financial information on the systematic risk of stock manufacturing companies listed on the Indonesia Stock Exchange. The financial information is measured in four variables, namely financial leverage, liquidity, profitability, and the size of the company.

\section{Literature review}

\subsection{Financial information and decision usefulness.} The main purpose of financial accounting is to present information that is useful for the users to make decisions. The financial information presented in the financial statements are the product of accounting, so that financial information can be referred to as the accounting information. However, in this paper the authors work in terms of financial information. Investors need financial information as a basis for the analysis of investment decisions.

Financial information is a fundamental requirement for the (potential) investors for making investment decisions. Investors often use accounting information disclosed to the public because the information has a signal about the prospects of a company in the future (Sulistio, 2005; Zuhrohtun dan Baridwan, 2005; Scott, 2009; Puspitaningtyas, 2012; 2015). Accounting information is complete, accurate and timely possible for investors to make rational decisions so that the results are expected.

Accountants, as the accounting information provider should be able to understand, what the purpose and benefits of their financial information, presented in the financial statements of a company for the users of information, so that the information presented can actually be beneficial to the users in the process of rational decision making. 
For purposes of presentation of financial information is to facilitate the decision-making process for the users of accounting information. SFAC 1 presents the adaptation of decision theory to the financial statements (accounting) to provide accounting information useful to investors, creditors, and other users in making rational investment decisions (Scott, 2009; Puspitaningtyas, 2012; 2015).

\subsection{Portfolio diversification strategy and system-} atic risk $(\boldsymbol{\beta})$. Diversification strategy, namely to invest in a portfolio of securities, is one way for investors to reduce or minimize the risk without reducing expected returns. Diversification is meant to add securities in the portfolio in order to reduce total risk. If the two stocks portfolio of the is better than one, then the three stock portfolios should be better than two, and so on. Portfolio diversification principle states that the risk can be eliminated (but not all) with the implementation of the investment strategy (Scott, 2009; Sudarsono, Husnan, Tandelililn and Ekawati, 2012; Toth, Lancaric, Piterkova and Savov, 2014; Puspitaningtyas, 2015).

There are two types of risk in investments (Harianto dan Sudomo, 1998; Estrada, 2002; Bodie, Kane and Marcus, 2009; Sudarsono, Husnan, Tandelililn and Ekawati, 2012, 2012; Toth, Lancaric, Piterkova and Savov, 2014; Puspitaningtyas, 2015), namely: (1) Systematic risk, and (2) unsystematic risk. Summation of systematic risk and unsystematic risk is the risk of the total shares of the company. Unsystematic risk is the risk that can be eliminated through diversification in the portfolio, the source comes from internal factors (micro), and this risk affects one (small group) company, such as an increase in sales of the company were higher than expected.

Meanwhile, systematic risk is an inherent risk, a risk that can not be eliminated through diversification in the portfolio, the source of this risk comes from external factors (macro) such as inflation, the announcement of changes in interest rates, and this risk affects all the (many) companies. Systematic risk of each company will be correlated, otherwise unsystematic risk is not correlated (Harianto dan Sudomo, 1998; Estrada, 2002; Sudarsono, Husnan, Tandelililn and Ekawati, 2012; Toth, Lancaric, Piterkova and Savov, 2014; Puspitaningtyas, 2015).

Investors pursuing a strategy of investing in a portfolio of securities (shares) on the grounds, if investors added more than two types of securities in the portfolio (many securities), the benefit of reducing the risk that investors will get bigger until it reaches a certain point, where the benefits of these reductions began to decrease. When public resources on securities risk affect all companies, even the expansion of diversification can not eliminate the risk. In other words, risk can occur again after the expansion of diversification. Such risk is referred to as market risk or systematic risk, or the risk that can not be diversified (non-diversification risk). In contrast, the risk can be eliminated by diversification and is called unique risk or firm-specific risk or unsystematic risk or the risk that can be diversified (diversifiable risk) (Estrada, 2002; Bodie, Kane and Marcus, 2009; Toth, Lancaric, Piterkova and Savov, 2014; Puspitaningtyas, 2015).

Systematic risk is defined as the beta $(\beta)$ and plays an important role in the diversification principle to measure the risk of the securities. Because some of the risk can be eliminated through diversification strategies, the risk of missing parts has become irrelevant in the measurement of risk and this risk can be ignored. Relevant risk in the measurement of risk is the risk that can not be lost through diversification, this risk is called systematic risk or beta $(\beta)$ (Harianto dan Sudomo, 1998; Hartono, 2008; Scott, 2009; Estrada, 2002; Anjum, 2014; Toth, Lancaric, Piterkova and Savov, 2014; Puspitaningtyas, 2015). Thus, the risk represented by beta is systematic risk of a security or a portfolio and risk is associated with the level of expected profit. Beta is a measure of the movement between the change in the price of securities and changes in the market value of the market portfolio. Beta is a measure of the return movement of securities (portfolio) to market return. This paper intends to analyze whether a systematic risk is still relevant as an indicator measuring investment risk. If the systematic risk can be predicted using financial information so it is useful for making investment decisions.

1.3. Estimating beta. Knowing the beta of a securities or a portfolio is essential to analyze the securities or portfolios, they are also useful as consideration for entering into the securities portfolio formation. To calculate the portfolio beta, beta first needs to be calculated each of the securities. Calculating the risk of a portfolio is not only by adding up all the individual securities in the portfolio at risk. In other words, the risk of the portfolio is not the sum of the risk of individual securities in the portfolio. Beta portfolio is a weighted average of each of the securities beta. Thus, the portfolio beta can be calculated as a weighted average (by proportion) of each of the individual securities that make up the portfolio (Hartono, 2008; Bodie, Kane and Marcus, 2009; Toth, Lancaric, Piterkova and Savov, 2014; Puspitaningtyas, 2015).

Beta of a securities can be calculated through estimation techniques, using historical data in the form of market data and accounting data or fundamental data of a company. Estimating the beta of a securities can be done by regressing the return of securi- 
ties (as dependent variable), and the market return (as independent variables). The resulting regression equation of time series data will produce beta coefficients, assumed to be stable over time during the period of observation (Hartono, 2008; Puspitaningtyas, 2015).

There are two stages in estimating beta (Chun dan Ramasamy, 1989; Tandelilin, 1997; Sufiyati dan Na'im, 1998; Puspitaningtyas, 2015), that is:

1. The first stage: determining the individual stock return $\left(R_{i}\right)$ and the market return $\left(R_{m}\right)$.

- Calculating stock return $i$ in period $t$ with the formula:

$R_{i, t}=\left(P_{i, t_{+}} P_{i, t-1}\right) / P_{i, t-1}$,

$R_{i, t}=$ return of stock $i$ in period $t ; P_{i, t}=$ price of stock $i$ in period $t$.

- Determine the market return in period $t$ is calculated by:

$R_{m, t}=\left(R_{m, t}-R_{m, t-1}\right) / R_{m, t-1}$,

$R_{m, t}=$ return the market portfolio in period $t$.

2. The second stage: the coefficient estimates $\beta$ (systematic risk) by regressing between stock returns $i\left(R_{i, t}\right)$ and the market return $\left(R_{m, t}\right)$ in period $t$, by the equation:

$$
\begin{aligned}
& R_{i, t}=\alpha_{i}+\beta_{i} R_{m, t}+\varepsilon_{i, t}, \\
& \varepsilon_{i, t}=\text { variable error. }
\end{aligned}
$$

\subsection{Accounting variables and the systematic risk.}

This paper gives the meaning of the variable accounting as a variable that presents the information (data) from the accounting of firm's financial accounting process and presented in the financial statements of a company. Accounting variables have the same meaning as the fundamental financial variables or variable. Accounting variables present accounting information that can be used to determine the systematic risk (beta) shares of the company. Variable accounting is generally presented as a ratio of finance. This paper aims to analyze the influence of variables in financial leverage, liquidity, profitability, and the size of the company against systematic risk by using multiple linear regression analysis.

1.5. Financial leverage and the systematic risk. Financial leverage indicates, how much the company's operations are financed with debt. Financial leverage is an accounting variable, related to the use of funds that have a fixed load with the hope to increase the revenue. One way to measure variables is to use the financial leverage ratio of total debt, which is the ratio between total debt (the sum of long-term debt and short-term debt) to total assets.
This measurement shows how much the amount of the company's assets are financed by debt or capital from creditors (Syamsuddin, 2007; Artikis and Nifora, 2013; Puspitaningtyas, 2010; 2011; 2015; Shahzad, Ali, Ahmad and Ali, 2015).

Brealy and Myers in Gumanti (2003), Puspitaningtyas (2011), and Mishra and Modi (2013) revealed that the finance literature states the variability value of companies, affected by the influx of debt into capital structure. When debt incorporated into the company's capital structure, resulting in volatile earnings stream. This will increase the risk of stock and contribute to its shareholders to obtain a higher return.

Hamada (1969; 1972), Rubenstein (1973), Ben Zion and Shalit (1975), Christie (1982), Puspitaningtyas (2010; 2011), and Shahzad, Ali, Ahmad and Ali (2015) revealed the company's risk as a function of financial leverage. Dhingra (1982) states that financial leverage is one of the predictors of the risk of the company, that the expected risk of a firm is positively related to financial leverage. Gahlon (1981), Gahlon and Gentry (1982), and Mandelker and Rhee (1984) provide a theoretical model and empirical evidence that financial leverage in determining the potential risk of the company.

Financial leverage is predicted to have a positive relationship with systematic risk. The higher the ratio, the greater the assets means companies are financed with debt. This reflects a significant risk to the company. Their business debt is high, causing high debt burden, and the systematic risk also becomes higher (Beaver, Kettler and Scholes, 1970; Puspitaningtyas, 2010; 2011).

The study by Beaver, Kettler and Scholes (1970) using the ratio between the long-term debt to total assets, proving financial leverage positive influence on systematic risk. Tandelilin (1997) using the ratio between total debt with its own capital, also proved positive influence of variable financial leverage on a systematic risk

Meanwhile, Chun and Ramasamy (1989) using the ratio of long-term debt to shareholders' funds, found the negative influence of financial leverage variable on a systematic risk. Sufiyati and Na'im (1998) measure financial leverage to the average of the percentage change in earnings after interest and taxes divided by the percentage change in net operating income, or earnings before interest and taxes proves that financial leverage variables negatively affect systemic risk.

This study, using measurements of long-term debt, divided by total assets predicting that the variable financial leverage positively affects systematic risk, 
because the greater the company's assets financed with debt, the greater the composition of debt in the capital structure. This reflects the higher the risk that the company will accept. Financial leverage (FL) in periodt is measured using the ratio of longterm debt (LTD) in period $t$ with total assets (TA) in period $t$ :

$F L_{t}=L T D_{t}: T A_{t}$.

\section{$H_{1}$ : Financial leverage affects the systematic risk.}

1.6. Liquidity and the systematic risk. Liquidity indicates how much a company's able to pay shortterm financial obligations at maturity using available liquid assets. One way of measuring the liquidity variables is to use the current ratio, i.e. the ratio between current assets by current liabilities. This measurement shows, how much the company's ability to pay current liabilities with current assets available (Syamsuddin, 2007; Panwala, 2009; Puspitaningtyas, 2010; 2011; 2015; Niresh, 2012; Rajdev, 2013; Putra, Lahindah and Bambang, 2014; Ismail, 2016).

Liquidity is predicted to have a negative effect on the systematic risk (Beaver, Kettler and Scholes, 1970; Dhingra, 1982; Selva, 1995; Puspitaningtyas, 2010; 2011; 2015). Relatively high liquidity does not only reflect that the company has the ability to repay short-term liabilities or maturing, but also reflects that the company has the level of adaptation to environmental changes is higher. Thus earning a lower degree of uncertainty and risk that will be accepted is lower (Dhingra, 1982). Logically, it is known that the more liquid the company, the smaller the risk. Thus, the high level of liquidity should reflect that the company has a low risk.

Chun and Ramasamy (1989) by using the current ratio and Tandelilin (1997) by using the quick ratio prove that liquidity variables negatively affect systemic risk. In contrast, using the same measurement of liquidity variables with Chun and Ramasamy (1989), the positive influence of the liquidity variables to systematic risk found in the study of Belkaoui (1978) and Capstaff (1992).

This study, using measurements of current assets divided by current liabilities, predicts that the negative effect on the liquidity is of systematic risk. Because, the more liquid is a company, then the company is considered to have the ability to pay short-term obligations or liabilities maturing. In addition, the company also is considered to be in a relatively stable financial condition, it reflects the risks facing the company will be smaller. Liquidity (Li) in period $t$ is measured using the ratio of current assets (CA) in period tand the current liabilities $(\mathrm{CL})$ in period $t$ :
$L i_{t}=C A_{t}: C L_{t}$.

\section{$\mathrm{H}_{2}$ : Liquidity affect the systematic risk.}

1.7. Profitability and the systematic risk. Profitability shows the ability of the company to benefit from a number of funds invested in the total assets. One way is to use a profitability measure return on equity, which is the ratio between the net profit after taxes to stockholders equity. This measurement indicates the level of net income derived owners of companies on capital invested (Syamsuddin, 2007; Panwala, 2009; Niresh, 2012; Rajdev, 2013; Puspitaningtyas, 2010; 2011; 2015; Ismail, 2016; Jami and Bahar, 2016).

Profitability levels were tested for their investor considerations regarding the effectiveness of business operations, determined from the profitability of the past (Gumanti, 2003; Puspitaningtyas, 2015). The level of profitability demonstrates the effectiveness of the company's operations in making a profit. Profitability is predicted to have a positive influence on systematic risk, meaning that the higher profitability will lead to acceptable risk, and a company will be higher as well. Risk and profitability, the investment theory are always connected positively (Dhingra, 1982).

Tandelilin (1997) by using the net profit margin measurements prove the positive effect on the profitability of systematic risk. Instead, using the measurement of gross profit margin, it was found negative influence of the variable profitability of the systematic risk. Chun and Ramasamy (1989) using the measurement of net income after taxes before extra-ordinary items divided by shareholders' funds, also found a negative effect on the profitability of the systematic risk variables.

This study, using measurements of net profit after tax divided by capital itself, predicts that the positive effect on the profitability of systematic risk. Because, the higher the level of profitability of a company, the higher the risk that the company will accept. The greater the returns obtained by the owner of the company, the greater the risk is accepted. Profitability (Pr) in period $t$ is measured using the ratio of net profit after tax (EAT) in period $t$ and owner's equity (Eq) in period $t$ :

$P r_{t}=E A T_{t}: E q_{t}$.

\section{$\mathrm{H}_{3}$ : Profitability affect the systematic risk.}

1.8. Firm size and the systematic risk. Large company predicted has low risk, and the relationship between firm size and risk is negative (Ben Zion and Shalit, 1975; Dhingra, 1982; Capstaff, 1992; Selva, 1995). Beaver, Kettler and Scholes (1970) and Asgari, Pour, Zadeh and Pahlavan (2015) state 
that the size of the company can be used as a proxy for determining the total risk of a company, that large companies have a smaller risk than small firms. Firm size as a measure of total assets predicted to have a negative influence on the systematic risk. The variable firm size is determined by using the logarithm of total assets each year, the assets used as a proxy measure of the size of the company.

Dhingra (1982), Amato and Amato (2007; 2012), and Asgari, Pour, Zadeh and Pahlavan (2015) revealed that in general, large companies have a broader spectrum of activity, than small enterprises, so that the stock price and return on equity of large enterprises become relatively more stable. Therefore, large companies are considered to have less risk, than small firms. In addition, large companies tend to be known by investors, assumed to have access to capital markets, the information needed for investment is also likely to be more available, resulting in large company stocks tend to be more liquid with lower expected risk. Based on the above argument is predicted that the size of the company negatively affects systematic risk, which means that large companies tend to have a smaller, risk than small firms.

Capstaff (1992) by using measurements of natural logarithm of the book value of total assets found that the variable size of the company has a negative influence on the systematic risk. Conversely, a positive effect was found in the study Tandelilin (1997), which assesses the firm size variable using total assets of the company in period $t$.

This study using measurements of the total assets of the company predicts the size of the positive effect on systematic risk. Because, the bigger the size of the company (measured by total assets) the greater the investments in the total assets greater. Consequently, the share price will be higher, the expected return is also higher, consequently the risks facing the company will also be higher. The firm size in period $t$ measured using the logarithm of total assets (Log-TA) in period $t$ :

$F Z_{t}=\log -T A_{t}$.

$\mathrm{H}_{4}$ : Firm size affecs the systematic risk.

\section{Methodology}

This section of the study sets out the population and sampling technique, and the analysis methods.

2.1. The population and sampling technique. The respondents in this research include manufacturing companies listed in Indonesia Stock Exchange, which amounted to 150 companies. The manufacturing company selected as research subjects by reason of the company relative, has the same prop- erties that use the same fixed assets with a fixed load is relatively large (such as the use of machines and other production equipment) in its operations.

Sampling was done by purposive sampling technique, namely choosing a sample based on defined criteria adapted for the purpose of research, as many as $n$ sample companies. Furthermore, a number $n$ of samples multiplied by the company's five-year study period (2011-2015) will be the total number of observations (observation frequency), as many as $n$ observations.

The criteria set for the sampling are as follows:

- The Company publishes financial information period 2011-2015.

- The Company has a weekly stock price information for the period January 2011-December 2015.

Based on the sampling criteria, this sample amounted to 127 companies. Observance of the variables measured, in the span of five years (20112015), is arranged in a time series. Companies that become sample of 127 companies with a range of observation time of five years, with the frequency of observation as much as 635 observations $(n=635)$.

2.2. The analysis methods. Data were analyzed using multiple linear regression analysis. Multiple linear regression analysis model in general is (Gujarati, 2003): $Y_{t}=b_{1}+b_{2} X_{2 t}+b_{3} X_{3 t}+\mu_{t}$. This study developed a model of multiple linear regression analysis as follows: $\beta_{t}=b_{1}+b_{2} F L_{t}+b_{3} L i_{t}+b_{4} P r_{t}+$ $b_{5} F Z_{t}+\mu_{t}$.

Inferential analysis is used for proving the hypothesis (hypothesis testing) to the regression coefficient. A statistical calculation is called significant if the value of the test statistics is in critical regions (regions where $\mathrm{H}_{0}$ is rejected). In contrast, so-called insignificant if the value of the test statistics is in areas where $\mathrm{H}_{0}$ is accepted. Formulation of hypotheses is as follows:

$H_{0}$ : the independent variables $\left(X_{i}\right)$ are not an significant explanatory to the dependent variable $(Y)$.

$H_{a}$ : independent variables $\left(X_{i}\right)$ are significant explanatory to the dependent variable $(Y)$.

There are three criteria for accuracy in regression analysis, namely:

- The $t$ test or the test of significance of individual (partial), i.e. a test that shows, how far the influence of the explanatory variables (independent) individually in explaining the variation of the dependent variable. The expected level of significance was $\alpha=5 \%=0.05$, or at a $95 \%$ confidence interval. If $t$ significance value is less than $0.05(p<0.05), \mathrm{H}_{0}$ is rejected and Ha accepted. 
- F-test or simultaneous significance test is a test that indicates, whether all the independent variables, contained in the regression model, have influence simultaneously on the dependent variable. The expected level of significance was $\alpha=$ $5 \%=0.05$ or $95 \%$ confidence intervals. If, $\mathrm{F}$ significance value is less than $0.05(p<0.05) \mathrm{H}_{0}$ rejected, and $\mathrm{Ha}$ is accepted.

- The coefficient of determination $\left(\mathrm{R}^{2}\right)$ is to measure, how far is regression model, obtained from the multiple linear regression analysis to explain variation in the dependent variable. The coefficient of determination is between 0 and 1 . Value $\mathrm{R}^{2}$ is small, and means that the ability of the independent variables in explaining the variation of the dependent variable is very limited. Value close to 1 means that the independent variables provide almost all the information, necessary to predict the variation of the dependent variable.

\section{Results}

Multiple linear regression analysis was conducted to determine the effect of financial leverage, liquidity, profitability, and the size of the company against systematic risk (beta / $\beta$ ). Table 1 presents the results of multiple linear regression analysis.

Based on these results, it appears that at the 0.05 level just large companies that have significant influence or a significant explanatory against systematic risk (accept $\mathrm{H}_{4}$ ). Meanwhile, financial leverage, liquidity, and profitability does not affect or is not a significant explanatory against systematic risk (refuse $\mathrm{H}_{1}, \mathrm{H}_{2}$, and $\mathrm{H}_{3}$ ). The results of the above analysis can be derived in the as model the following equation:

$\beta=-1.513+0.370 \mathrm{FZ}+\mathrm{e}$.

The equation model indicates that company size has positive influence on systematic risk.

Table 1 . The results of multiple linear regression analysis

\begin{tabular}{|c|c|c|c|c|c|}
\hline \multicolumn{3}{|l|}{ Multiple R } & \multicolumn{3}{|c|}{0.355} \\
\hline \multicolumn{3}{|l|}{ R square } & \multicolumn{3}{|c|}{0.126} \\
\hline \multicolumn{3}{|c|}{ Adjusted R square } & \multicolumn{3}{|c|}{0.120} \\
\hline \multicolumn{3}{|c|}{ Standard error of estimate } & \multicolumn{3}{|c|}{0.61282} \\
\hline \multicolumn{3}{|l|}{ F value } & \multicolumn{3}{|c|}{22.713} \\
\hline \multicolumn{3}{|l|}{ Sig. F } & \multicolumn{3}{|c|}{0.000} \\
\hline \multicolumn{6}{|c|}{ Variables in the equation } \\
\hline Variable & $B$ & Std. error & Beta & $t$ & Sig. \\
\hline $\mathrm{FL}$ & -0.117 & 0.081 & -0.054 & -1.437 & 0.151 \\
\hline $\mathrm{Li}$ & $-7.66 \mathrm{E}-04$ & 0.001 & -0.044 & -1.181 & 0.238 \\
\hline $\mathrm{Pr}$ & 1.675E-04 & 0.002 & 0.004 & 0.101 & 0.920 \\
\hline FZ & 0.370 & 0.039 & 0.355 & 9.395 & 0.000 \\
\hline (Constant) & -1.513 & 0.230 & & -6.572 & 0.000 \\
\hline
\end{tabular}

Source: results of the analysis.
Measurement problems of financial leverage, liquidity, and profitability may be one cause of the three accounting variables, indicating no effect on the systematic risk. Measurement of financial leverage ratio, liquidity, and profitability chosen as the basis of analysis, may be less able to provide a direct impact on systemic risk so it does not give effect to systematic risk. Instead, the analysis results also reflect that the total assets as a factor ratings of firm size variables can be used as a proxy to predict the magnitude of systematic risk. That is, the variable size of the companies represented by the total size of assets, can provide information for investors to predict the systematic risk.

$\mathrm{F}$ test values $=22.713$, is significant at the 0.05 level. That is, that all the independent variables included in the regression model, ie financial leverage, liquidity, profitability, and the size of the company together (simultaneously) effect, or a significant explanatory variable beta. The coefficient of determination $\left(R^{2}\right)$ obtained is very small $\left(R^{2}=\right.$ 0.126). That is, the resulting regression model showed that the ability of variable financial leverage, liquidity, profitability, and the size of the company in explaining the variation of the variable beta is severely limited by $12.6 \%$. Meanwhile, the remaining balance of $87.4 \%$, is explained by other variables (e) were not observed.

Problems variable measurement of financial leverage, liquidity, profitability, and the size of the company, may be the cause of the inconsistency of the results of research on the effect of financial leverage, liquidity, profitability, and the size of the company against systematic risk. Despite many studies that provide empirical evidence about the effect of financial leverage, liquidity, and profitability of the systematic risk, there is no provision of measurement of financial leverage, liquidity, profitability, and the size of the enterprise standard to determine its effect on systemic risk. As a result, the selection of accounting measurement variables to be biased. Thus, the absence of a standard measurement and may be the cause of inconsistencies in research results.

Use of the study sample and the period of implementation of different studies may also be a factor contributing to inconsistency of research results. The use of different samples lead to different data sources, so that the financial and economic indicators are also different. This is because the analysis model used is not able to control the influence of culture, market transactions, and financial and economic conditions are different. So that different samples may cause the results, not consistent with other studies. 
The period of implementation of different researches indicates situations and different capital market conditions, which, over time, if there is a change in the situation and condition of the capital market environment. Capital markets in Indonesia, including the capital market that is growing, so there is a tendency to instability of capital markets behavior changes compared with established capital markets (such as the New York Stock Exchange / NYSE). This condition may cause the results obtained are not consistent.

Multiple linear regression model produced showed that the ability of variable financial leverage, liquidity, profitability, and firm size variables in explaining the variation of systematic risk is very limited. It shows there are many other variables that affect the company's stock systematic risk. This study only considers four accounting variables. Future research may consider other accounting variables that predicted effect on systematic risk, for example, variable and variable capital market activity (such as price earnings, price-book value, dividend yields and earnings per share).

In addition, this study uses only one measurement for each variable accounting. Perhaps the selection of these variables is less precise measurements, so that the results are not significant. Future research may consider measurements of other accounting variables; mainly choose the variables that predicted measurements, which provide a major influence on systematic risk. For example, using the measurement of total debt to total equity and longterm debt to total equity for the measurement of financial leverage variables. Because equity related to the return to be received by investors, and returns are affected by risk, so investors tend to stabilize the investment risk. Measurement of quick assets to current liabilities, current assets to total assets, and current liabilities to total assets for the measurement of liquidity variables. And, the measurement of net profit margin and return on investment for the measurement of profitability variable.

\section{Conclusions}

Based on the analysis we can conclude that at the 0.05 level only variable sized companies that significantly influence systematic risk, which means that the variable firm size is the determining factor that can affect systematic risk of shares to be borne by investors. Conversely, variable financial leverage, liquidity, and profitability have less direct impact that could affect the company's stock systematic risk, because the three accounting variables showed no effect on systemic risk.

Regression model showed that the variables of financial leverage, liquidity, profitability, and size of enterprises simultaneously are a significant explanatory against systematic risk stock company. The coefficient of determination of $12.6 \%$ indicates that the ability of the four accounting variables, included in the regression equation models, are very limited in explaining the variation of systematic risk variable shares of the company. The results showed inconsistencies with the results of several previous studies. This inconsistency may be due to measurement problems variable accounting, the implementation period of the study, and the use of different research samples.

Suggestions for further research that would do this kind of research to develop a variable of accounting and measurement accounting variables that predicted effect on the company's stock systematic risk and apply it to other types of companies, listed on the Indonesia Stock Exchange with a longer observation time.

\section{References}

1. Amato, L. H. and Amato, C. H. (2007). Retail Philanthropy: Firm Size, Industry, and Business Cycle. Journal of Business Ethics, 107(4), 435-448.

2. Amato, L. H., and Amato, C. H. (2012). The Effects of Firm Size and Industry on Corporate Giving. Journal of Business Ethics, 72(3), 229-241.

3. Anjum, S. (2014). Systematic Risk Outliers and Beta Reliability in Emerging Economics: estimation-Risk Reduction with AZAM Regression. Review of Integrative Business and Economics Research, 3(1), 288-302.

4. Artikis, P. G., and Nifora, G. (2013). Leverage Premium in a Southern European Frame. Journal of Computational Optimization in Economics and Finance, 5(1), 1-26.

5. Asgari, M. R., Pour, A. A. S., Zadeh, R. A., and Pahlavan, S. (2015). The Relationship Between Firm's Growth Opportunities and Firm Size on Changes Ratio in Retained Earnings of Listed Companies in Tehran Stock Exchange. International Journal of Innovation and Applied Studies, 10(3), 923-931.

6. Beaver, W. H. Kettler, P., and Scholes, M. (1970). The Association Between Market Determined And Accounting Determined Risk Measures. The Accounting Review, 654-682.

7. Belkaoui, A. (1978). Accounting Determinants of Systematic Risk in Canadian Common Stocks: a Multivariate Approach. Accounting and Business Research, 3-10.

8. Ben-Zion, U., and Shalit, S. S. (1975). Size, Leverage, and Dividend Record as Determinants of Equity Risk. The Journal of Finance, 30(4), 1015-1026.

9. Bera, A. K., and Kannan, S. (1986). An Adjustment Procedure For Predicting Systematic Risk. Journal of Applied Econometrics, 1(4), pp. 317-332. 
10. Bodie, Z., Kane, A., and Marcus, A. J. (2009). Investment. $8^{\text {th }}$ edition. McGraw-Hill Companies, Inc.

11. Capstaff, J. (1992). The Usefulness of UK Accounting and Market Data for Predicting the Perceived Risk Class of Securities. Accounting and Business Research, 219-228.

12. Christie, A. A. (1982). The Stochastic Behavior of Common Stock Variances: Value, Leverage, and Interest Rate Effect. Journal of Financial Economics, 407-432.

13. Chun, L. S. and Ramasamy, M. (1989). Accounting Variables as Determinants of Systematic Risk in Malaysian Common Stocks. Asia Pacific Journal of Management, 6(2), 339-350.

14. Dhingra, H. L. (1982). The Impact of Accounting Variables on Stock Market Measures of Risk. Accounting And Business Research, 193-201.

15. Estrada, J. (2002). Systematic Risk in Emerging Markets: the D-CAPM. Emerging Marets Review, 3, $363-379$.

16. Fama, E. F., and French, K. R. (2004). The Capital Asset Pricing Model: Theory and Evidence. Journal of Economic Perspectives, 18(3), 25-46.

17. Gahlon, J. M. (1981). Operating Leverage as a Determinant of Systematic Risk. Journal of Business Research, 9(2), 297-308.

18. Gahlon, J. M., and Gentry, J. A. (1982). On the Relationship Between Systematic Risk and the Degrees of Operating and Financial Leverage. Journal of Financial Management, 11(2), 15-23.

19. Gujarati, D. (2003). Basic Econometric. $3^{\text {th }}$ edition. McGraw-Hill Companies.

20. Gumanti, T. A. (2003). Can Accounting Information Act As A Proxy For Ex Ante Uncertainty In Initial Public Offerings? Gadjah Mada International Journal of Business, 5(2), 249-269.

21. Hamada, R. (1969). Portfolio Analysis, Market Equilibrium and Corporation Finance. Journal of Finance, 13-31.

22. Hamada, R. (1972). The Effect of the Firm's Capital Structure on the Systematic Risk of Common Stocks. The Journal of Finance, 435-452.

23. Harianto, F., and Sudomo, S. (1998). Perangkat dan Teknik Analisis Investasi di Pasar Modal Indonesia. Jakarta: PT. Bursa Efek Jakarta.

24. Hartono, J. (2008). Teori Portofolio dan Analisis Investasi. Edisi Kelima, Yogyakarta: BPFE.

25. Homan, A. (2006). The Impact of $9 / 11$ on Financial Risk, Volatility and Returns of Marine Firms. Maritime Economics \& Logistics, 8, 387-401.

26. Ismail, R. (2016). Impact on Liquidity Management on Profitability of Pakistani Firms: A Case of KSE-100 Index. International Journal of Innovation and Applied Studies, 14(2), 304-314.

27. Jami, M. and Bahar, M.N. (2016). Analysis of Profitability Ratios to Evaluation of Performance of Indian Automobile Industry. Journal of Current Research in Science, 747-755.

28. Lai, T. Y., and Stohs, M. H. (2015). Yes, CAPM Is Dead. International Journal of Business, 20(2), 144-158.

29. Mandelker, G. N., and Rhee, S. G. (1984). The Impact of The Degrees of Operating and Financial Leverage on Systematic Risk of Common Stock. Journal of Financial and Quantitative Analysis, 1(1), 45-57.

30. Mishra, S., and Modi, S. B. (2013). Positive and Negative Corporate Social Responsibility, Financial Leverage, and Idiosyncratic Risk. Journal of Business Ethics, 117(2), 431-448.

31. Niresh, J. A. (2012). Trade-off Between Liquidity \& Profitability: A Study Of Selected Manufacturing Firms in Sri Lanka. Researchers World, 3(4), 34-40.

32. Panwala, M. (2009). Dimension of Liquidity Management - a Case Study of the Surat Textile's Traders CoOperatve Bank LTD, Surat. National Journal of System and Information Technology, 2(1), 117-126.

33. Puspitaningtyas, Z. (2010). Manfaat Informasi Akuntansi Untuk Memprediksi Risiko Investasi Saham Berdasarkan Pendekatan Decision Usefulness. Jurnal Akuntansi Multiparadigma, 1(3), 467-488.

34. Puspitaningtyas, Z. (2011). Pembentukan Model Prediksi Risiko Investasi Saham Berdasarkan Decision Usefulness Approach of Accounting Information. Prosiding Seminar Nasional dan Call for Paper 2011: Kajian Penelitian Aktual Guna Pengembangan Teori Baru Bidang Ekonomi dan Bisnis, 43-58.

35. Puspitaningtyas, Z. (2012). Relevansi Nilai Informasi Akuntansi dan Manfaatnya Bagi Investor. Ekuitas: Jurnal Ekonomi dan Keuangan, 16(2), 164-183.

36. Puspitaningtyas, Z. (2015). Prediksi Risiko Investasi Saham: Decision Usefulness Approach. Yogyakarta: Griya Pandiva.

37. Putra, A. P., Lahindah, L., and Bambang, R. (2014). Financial Performance Analysis Before and After Global Crisis (Case Study in Indonesian Oil and Gas Sector for the Period of 2016-2011). Review of Integrative Business and Economics Research, 3(1), 42-51.

38. Radjev, A. (2013). Working Capital Management of Makson Healthcare PVT LTD: a Trade-off Between Liquidity and Profitability, an Empirical Study. International Refereed Research Journal, 4(3), 87-94.

39. Rubenstein, M. E. (1973). A Mean Variance Synthesis of Corporate Financial Theory. Journal of Finance, $167-181$.

40. Scott, W. R. (2009). Financial Accounting Theory. $4^{\text {rd }}$ edition, Toronto, Ontario: Prentice Hall, Inc.

41. Selva, M. (1995). The Association Between Accounting Determined Risk Measures and Analysts' Risk Perceptions in a Medium-Sized Stock Market. Journal of International Financial Management and Accounting, 207-229.

42. Shahzad, S. J. H. Ali, P. Ahmad, T., and Ali, S. (2015). Financial Leverage and Corporate Performance: Does Financial Crisis Owe an Explanation? Pakistan Journal of Statistics and Operation Research, 11(1), 67-90.

43. Sudarsono, R., Husnan, S., Tandelilin, E., and Ekawati, E. (2012). Time Varying Beta (Dual Beta): Conditional Market Timing CAPM. Manajemen \& Bisnis, 11(2), 269 p. 
44. Sufiyati. Na'im, A. (1998). Pengaruh Leverage Operasi Dan Leverage Finansial Terhadap Risiko Sistematik Saham: Studi Pada Perusahaan Publik Di Indonesia. Jurnal Ekonomi dan Bisnis Indonesia, 13(3), 57-69.

45. Sulistio, H. (2005). Pengaruh Informasi Akuntansi dan Non Akuntansi terhadap Initial Return: Studi pada Perusahaan Yang Melakukan Initial Public Offering di Bursa Efek Jakarta. SNA 8 Solo, 87-99.

46. Syamsuddin, L. (2007). Manajemen Keuangan Perusahaan (Konsep Aplikasi dalam: Perencanaan, Pengawasan, dan Pengambilan Keputusan). Jakarta: PT. RajaGrafindo Persada.

47. Tandelilin, E. (1997). Determinants of Systematic Risk: The Experience of Some Indonesian Common Stock. Gadjah Mada University, 101-123.

48. Toth, M., Lancaric, D., Piterkova, A., and Savov, R. (2014). Systematic Risk in Agriculture: A Case of Slovakia. AGRIS On-line Papers in Economics and Informatics, 6(4), 185-193.

49. Zuhrohtun, Baridwan, Z. (2005). Pengaruh Pengumuman Peringkat Terhadap Kinerja Obligasi. SNA 8 Solo, 355-366. 